\title{
Molecular Population Genetic Analysis Differentiates Two Virulence Mechanisms of the Fungal Avirulence Gene NIP1
}

\author{
Stéphanie Schürch, ${ }^{1}$ Celeste C. Linde, ${ }^{1}$ Wolfgang Knogge, ${ }^{2}$ Lee F. Jackson, ${ }^{3}$ and Bruce A. McDonald ${ }^{1}$ \\ ${ }^{1}$ Institute of Plant Sciences, Plant Pathology Group, Federal Institute of Technology, Universitätstrasse 2, CH-8092 Zürich, \\ Switzerland; ${ }^{2}$ School of Agriculture and Wine, The University of Adelaide, Glen Osmond, SA 5064, Australia; ${ }^{3}$ Department of \\ Agronomy \& Range Science, University of California, Davis, CA 95616, U.S.A.
}

Submitted 5 January 2004. Accepted 21 May 2004.

Deletion or alteration of an avirulence gene are two mechanisms that allow pathogens to escape recognition mediated by the corresponding resistance gene in the host. We studied these two mechanisms for the NIP1 avirulence gene in field populations of the fungal barley pathogen Rhynchosporium secalis. The product of the avirulence gene, NIP1, causes leaf necrosis and elicits a defense response on plants with the $\operatorname{Rrs} 1$ resistance gene. A high NIP1 deletion frequency $(45 \%)$ was found among 614 isolates from different geographic populations on four continents. NIP1 was also sequenced for 196 isolates, to identify DNA polymorphisms and corresponding NIP1 types. Positive diversifying selection was found to act on NIP1. A total of 14 NIP1 types were found, 11 of which had not been described previously. The virulence of the NIP1 types was tested on Rrs1 and rrs 1 barley lines. Isolates carrying three of these types were virulent on the Rrs1 cultivar. One type each was found in California, Western Europe, and Jordan. Additionally, a field experiment with one pair of near-isogenic lines was conducted to study the selection pressure imposed by Rrs 1 on field populations of $R$. secalis. Deletion of NIPI was the only mechanism used to infect the Rrs 1 cultivar in the field experiment. In this first comprehensive study on the population genetics of a fungal avirulence gene, virulence to Rrs1 in $R$. secalis was commonly achieved through deletion of the NIP1 avirulence gene but rarely also through point mutations in NIP1.

Additional keywords: leaf scald of barley, neutral theory, nonsynonymous mutations, synonymous mutations.

Because plants are often attacked and infected by pathogens, many different forms and levels of plant-pathogen interactions have evolved. One type of interaction takes place between plant resistance genes and pathogen avirulence genes as described by Flor's gene-for-gene model (1955). Resistance genes permit recognition of pathogen elicitors encoded by the avirulence genes that activate the plant defense system. Deleted or altered avirulence genes allow pathogens to escape recognition by

Preliminary note: Throughout this paper, virulence is used as an antonym for avirulence and is defined as "the genetic ability of a pathogen race to overcome genetically determined host resistance (...) and cause a compatible (disease) interaction" (Shaner et al. 1992).

Corresponding author: S. Schürch;

E-mail: stephanie.schuerch@ipw.agrl.ethz.ch host plants, infection takes place, and virulent pathogens are said to overcome resistance. New resistance gene alleles allow plants to counter adapt. This antagonistic coevolution is expected to leave traces at the molecular level. Indeed, several plant resistance genes have been shown to be under positive diversifying selection (Bergelson et al. 2001). However, no information on adaptive evolution of avirulence genes is available.

The inactivation of avirulence genes can evolve through several mechanisms, including deletion of the entire gene, nonsynonymous point mutations, frameshift mutations, or transposon insertions. Mechanisms affecting regulation of gene expression may also be involved. In the tomato pathogen Cladosporium fulvum, the Avr9 avirulence gene is lacking from all strains virulent on host cultivars carrying the Cf-9 resistance gene (van Kan et al. 1991). In this same pathogen, virulence on $\mathrm{Cf}-2$ tomato plants occurs as a consequence of the production of truncated AVR2 proteins due to different types of mutations (Luderer et al. 2002). Virulence on Cf-4 plants was gained through point or frameshift mutations leading to unstable AVR4 isoforms of the elicitor (Joosten et al. 1997). Avirulence gene inactivation by insertion of a transposable element was reported for Avr2 (Luderer et al. 2002) and for the avirulence gene Avr-Pita of the rice pathogen Magnaporthe grisea (Kang et al. 2001).

A fungal avirulence gene has been identified in Rhynchosporium secalis (Oudem.) J. J. Davis, the causal agent of leaf scald of barley (Hordeum vulgare L.). This avirulence gene, termed AvrRrsl or NIP1, interacts with the Rrsl resistance gene of barley (Rohe et al. 1995). The product of AvrRrsl is a necrosis-inducing peptide, named NIP1 (Wevelsiep et al. 1991), that stimulates a $\mathrm{H}^{+}$-ATPase (Wevelsiep et al. 1993). Thus, NIP1 functions both as a toxin and an elicitor. Two other necrosis-inducing peptides, NIP2 and NIP3 (Wevelsiep et al. 1991), have not been found to elicit a resistance response (Hahn et al. 1993). Incompatible interactions with Rrs 1 barley cultivars are not accompanied by a hypersensitive response, but PR protein synthesis is induced (Hahn et al. 1993; Zareie et al. 2002). After spore germination and cuticle penetration, a few epidermal cells collapse, and fungal growth is stopped. In compatible interactions, collapse of many more epidermal cells is followed by the collapse of mesophyll cells, which results in visible lesions (Lehnackers and Knogge 1990). Fungal strains lacking NIP1 or strains with either one of two specific point mutations in NIPl were shown to overcome Rrsl resistance (Rohe et al. 1995). A study on Finnish $R$. secalis isolates found two other isoforms (Kilby and Robinson 2001). Another isoform was reported from $R$. secalis isolated from Atlas 46 in Canada (Johnson et al. 1996). 
Because $R$. secalis may cause significant yield losses when conditions are conducive for disease development (Shipton et al. 1974), many efforts for breeding resistant barley varieties have been undertaken. Several major resistance genes were identified (Goodwin et al. 1990). However, none of these genes have been cloned, and some of them may be alleles at one locus (Bjørnstad et al. 2002; Habgood and Hayes 1971). For most barley cultivars, it is not possible to know which resistance gene or genes they contain. Turk is an exception and is thought to contain the Rrs 1 resistance gene (symbol as in Søgaard and von WettsteinKnowles [1987] and Bjørnstad et al. [2002], originally $R h 3$ [Dyck and Schaller 1961]). The gene was introgressed into cultivar Atlas, which already contained $R h 2$ (Dyck and Schaller 1961). The newly obtained cultivar, Atlas 46 (Rrsl and Rh2) was released in California, but less than 10 years later it was fully susceptible to the local $R$. secalis population (Houston and Ashworth 1957). Turk's Rrsl gene was also introduced into Turk NIL, a near-isogenic line developed in the cultivar Ingrid as part of an effort to produce a set of differentials containing known resistance sources (Bjørnstad et al. 2002).

In this manuscript, we describe how the $R$. secalis-barley pathosystem was used to better understand avirulence gene evolution and the mechanisms leading to virulence and resistance gene breakdown. In particular, the mechanisms leading to inactivation of the NIPI avirulence gene in natural field populations were examined. First, the deletion frequencies of NIP1, NIP2, and NIP3 were quantified in different $R$. secalis populations around the world. Then, the NIPl locus was sequenced for a global collection of 196 isolates to determine the degree of polymorphism existing at this locus, to identify point mutations that inactivate the avirulence gene, and to test whether this gene is under positive diversifying selection. NIP1 isoforms were inferred from the DNA sequence data, and their global distribution was determined. The virulence of isolates carrying these isoforms was assessed on rrs1 and Rrs1 barley cultivars. Finally, we looked at the effect of selection imposed by the presence of Rrsl on NIPl in a natural $R$. secalis population in a field experiment.

\section{RESULTS}

Occurrence of the NIP1, NIP2, and NIP3 genes.

Deletion frequency of NIP1, NIP2, and NIP3 was assessed in $21 R$. secalis populations by hybridization of NIP probes to Southern blots containing genomic $R$. secalis DNA (Table 1). Overall, the NIPl gene was deleted in $45 \%$ of the 614 isolates tested. In the four Ethiopian populations, NIPl was deleted in all isolates. On the other hand, NIPI was present in all the isolates collected in Norway and in four of the eight Australian populations (RS96AUS2, 3, 4, and 7). Isolates with and without NIPl coexisted in 11 populations, with the percentage of isolates missing NIP1 ranging from 3 to $87 \%$.

Overall, the NIP2 gene was found in $92 \%$ of the 544 isolates tested and was present in all the isolates from 14 of the 21 populations. In a Swiss population (RS99CH1) collected

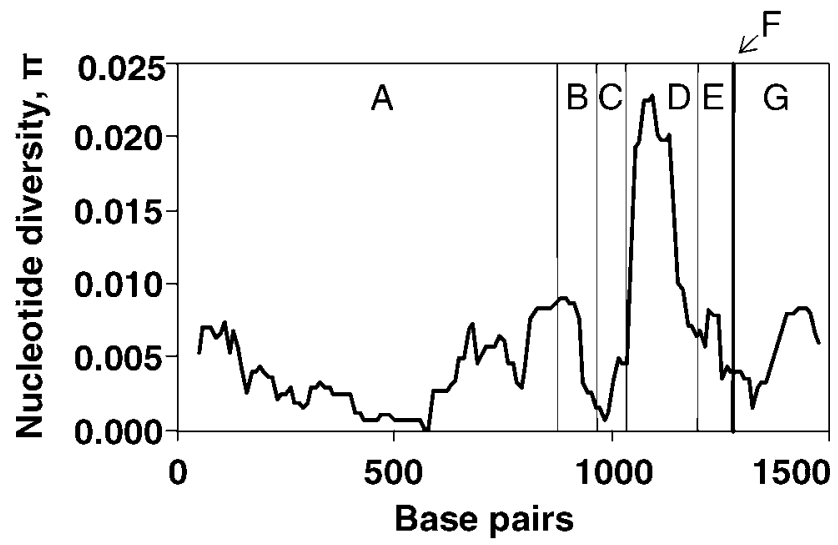

Fig. 1. Sliding window plot of the nucleotide diversity, $\pi$, across NIP1 in 49 haplotypes. Window size was 100 and step size 10 . The vertical bars delimit the different regions of NIP1. A, 5' flanking region (878 bp); B, 5' untranslated region (89 bp); C, signal peptide (66 bp); D, remainder of exon 1 (171 bp); E, intron (66 bp); F, exon 2 (9 bp); and G, 3' flanking region $(245 \mathrm{bp})$.

Table 1. Number and percentage of Rhynchosporium secalis isolates with (+ and \% +) and without (-)NIP1, NIP2, and NIP3 genes in 21 populations

\begin{tabular}{|c|c|c|c|c|c|c|c|c|c|c|}
\hline \multirow[b]{2}{*}{ Country } & \multirow[b]{2}{*}{ Population } & \multicolumn{3}{|c|}{ NIP1 } & \multicolumn{3}{|c|}{ NIP2 } & \multicolumn{3}{|c|}{ NIP3 } \\
\hline & & + & - & $\%+$ & + & - & $\%+$ & + & - & $\%+$ \\
\hline \multirow[t]{8}{*}{ Australia } & RS96AUS2 & 36 & 0 & 100 & 35 & 1 & 97 & 36 & 100 & \\
\hline & RS96AUS3 & 33 & 0 & 100 & 33 & 0 & 100 & 33 & 100 & \\
\hline & RS96AUS4 ${ }^{\mathrm{a}}$ & 26 & 0 & 100 & 26 & 0 & 100 & 26 & 100 & \\
\hline & RS96AUS5 & 32 & 1 & 97 & 24 & 9 & 73 & 33 & 0 & 100 \\
\hline & RS96AUS6R, $X^{a}$ & 20 & 15 & 57 & 34 & 1 & 97 & 35 & 0 & 100 \\
\hline & RS96AUS6BR ${ }^{b}$ & 0 & 2 & 0 & 2 & 0 & 100 & 2 & 0 & 100 \\
\hline & RS96AUS7 & 31 & 0 & 100 & 10 & 21 & 32 & 31 & 0 & 100 \\
\hline & RS96AUS8 & 5 & 23 & 17 & 28 & 0 & 100 & 28 & 0 & 100 \\
\hline \multirow[t]{4}{*}{ Ethiopia } & RS01ET1 & 0 & 28 & 0 & 26 & 0 & 100 & 26 & 0 & 100 \\
\hline & RS01ET2 & 0 & 13 & 0 & 12 & 0 & 100 & 13 & 0 & 100 \\
\hline & RS01ET3 & 0 & 31 & 0 & 28 & 0 & 100 & 29 & 0 & 100 \\
\hline & RS01ET4 & 0 & 28 & 0 & 21 & 0 & 100 & 22 & 0 & 100 \\
\hline Norway & RS90sNO & 36 & 0 & 100 & 36 & 0 & 100 & 35 & 0 & 100 \\
\hline \multirow[t]{7}{*}{ Switzerland } & $\mathrm{RS}_{99 \mathrm{CH}}{ }^{\mathrm{c}}$ & 8 & 12 & 40 & 0 & 12 & 0 & 17 & 1 & 94 \\
\hline & RS99CH2 & 12 & 16 & 43 & 17 & 0 & 100 & 26 & 0 & 100 \\
\hline & RS99CH5 & 7 & 20 & 26 & 22 & 0 & 100 & 26 & 0 & 100 \\
\hline & RS99CH6 & 16 & 17 & 48 & 13 & 0 & 100 & 30 & 0 & 100 \\
\hline & RS00CH & 6 & 39 & 13 & 42 & 1 & 98 & 42 & 1 & 98 \\
\hline & RS01CH1 & 27 & 5 & 84 & 27 & 0 & 100 & 27 & 0 & 100 \\
\hline & RS01CH2 & 23 & 15 & 61 & 31 & 1 & 97 & 29 & 0 & 100 \\
\hline California & RS88CAR & 17 & 13 & 58 & 31 & 0 & 100 & 31 & 0 & 100 \\
\hline Total & & 336 & 278 & 55 & 498 & 46 & 92 & 577 & 2 & 100 \\
\hline
\end{tabular}

a Isolates collected from barleygrass.

b Isolates collected from bromegrass.

${ }^{c}$ Isolates collected from rye. 
from rye, all isolates lacked NIP2, and in two Australian populations, RS96AUS5 and RS96AUS7, 27 and 68\% of the isolates, respectively, lacked NIP2. In four populations, single isolates had a NIP2 deletion. The NIP3 gene was found in all but two of the 579 isolates examined. One of the isolates lacking NIP3 was collected from rye in Switzerland, whereas the other one was also from Switzerland but was collected from barley.

To test whether gene deletion was independent among genes, linkage disequilibrium tests were applied. Neither twolocus tests for linkage disequilibrium nor a multilocus analysis were significant, and no disequilibrium could be detected. Therefore, gene deletion was independent among the NIP1, NIP2, and NIP3 genes.

\section{Variation in the NIP1 gene.}

A 1,524-bp long DNA sequence including NIPI was sequenced for 168 isolates. These sequences were deposited in GenBank (accession number AY507678 to AY507845). Among

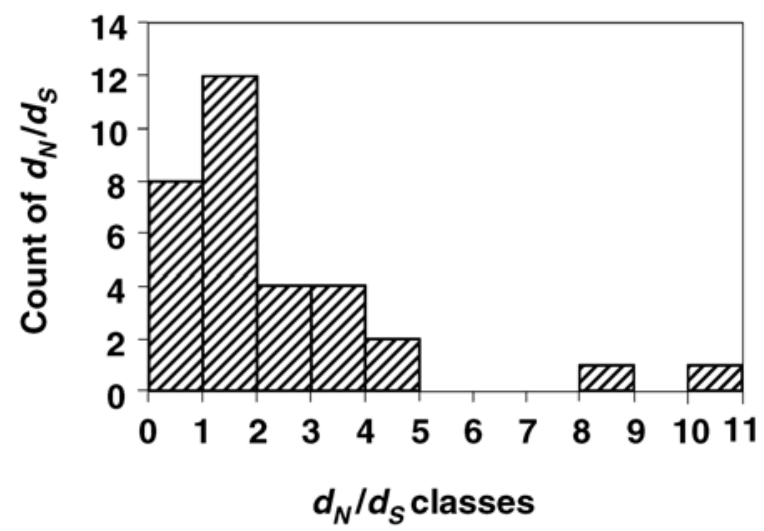

Fig. 2. Distribution of $d_{N} / d_{S}$ ratios for 32 pairwise comparisons among 15 NIP1 haplotypes into classes, where $d_{N}$ and $d_{S}$ are the number of nucleotide substitutions that cause amino acid replacements or are silent, respectively, divided by the number of possible substitutions of each type. $d_{N} / d_{S}>1$ indicates comparisons in which amino acid substitutions are more frequent than predicted by neutral substitution rates. these 168 isolates, 49 haplotypes were identified, with 93 polymorphic sites, of which 73 were parsimoniously informative. The nucleotide diversity across NIPl is shown in Figure 1 . The overall nucleotide diversity was $0.0057 \pm 0.0011$. Whereas the signal peptide was practically conserved (one polymorphic site out of 66), the remainder of the first exon had much higher nucleotide diversity $(0.0179 \pm 0.0020)$ than any other region. The other regions did not differ considerably in their level of nucleotide diversity.

\section{Tests of neutral selection.}

Tests of neutrality of mutations did not indicate a departure from neutrality in any of the NIPI regions considered. For tests based on comparisons of synonymous $\left(d_{S}\right)$ and nonsynonymous $\left(d_{N}\right)$ substitution rates, only the sequences coding for the mature NIP1 were used. Fifteen haplotypes were found. The haplotypes corresponding to NIP1 types 7 and 17, which are most likely not expressed (discussed below), were excluded from the analysis. Among the previously published NIP1 sequences, isolates AU2 and AU3 (Rohe et al. 1995) had a sequence different from those found in this study and were included in the analysis. Therefore, the analysis was conducted with 15 haplotypes in total.

In the sequences coding for the mature NIP1, there were 19 variable sites with a total of 23 mutations. One of these mutations was synonymous, 17 were nonsynonymous, and the remaining six mutations were all located at a single codon with a complex evolutionary pathway. Since only one synonymous mutation was present among the 15 haplotypes, $d_{S}$ was equal to zero in 73 out of 105 pairwise comparisons. For the remaining comparisons $\omega$ could be calculated and was higher than one in 31 out of 39 comparisons (distribution of $\omega$ is shown in Fig. 2). Over all sequences, $d_{S}$ was $0.0057 \pm 0.0042$, and $d_{N}$ was $0.0316 \pm 0.0104$, resulting in a $d_{N} / d_{S}$ ratio of 5.54 , which was significantly higher than $1(t=2.31, P<0.05)$, indicating positive diversifying selection.

A maximum likelihood (ML) method was also used to estimate $\omega$, the $d_{N} / d_{S}$ ratio. Under a model allowing for one $\omega$, $d_{N} / d_{S}$ was estimated to be $3.56(\ln =-379.90)$. This model fitted the data significantly better than a one-ratio model with $\omega$ fixed at one $(\ln =-381.87,2 \Delta 1=3.94$, d.f. $1, P<0.05)$, indi-

Table 2. Amino acid sequences of 17 NIP1 types as found in previous studies (1 to 7) and in the present study ( 8 to 17). Sequences of the mature proteins are shown using the one-letter code for amino acids

NIP1 mature protein

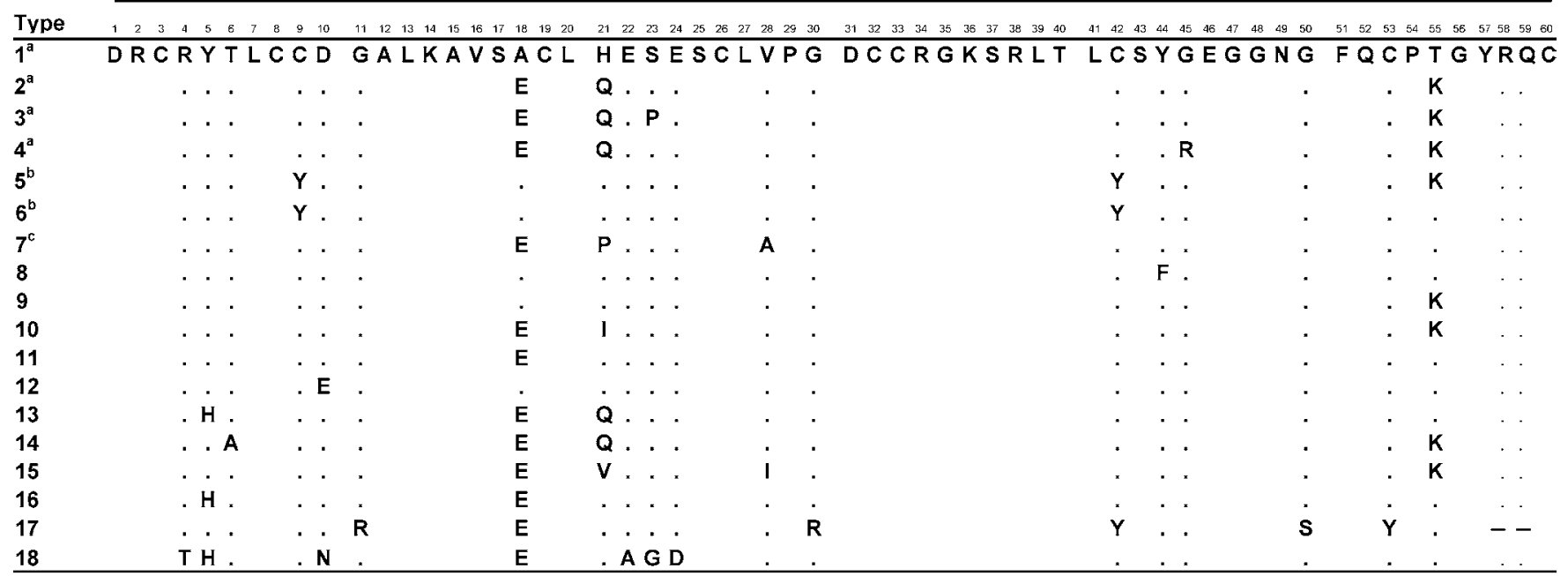

a Rohe et al. 1995.

${ }^{\mathrm{b}}$ Kilby et al. 2001.

c Johnson et al. 1996. 
cating that positive diversifying selection is acting on the NIPI gene. A neutral model $(\mathrm{ln}=-381.08)$ that allows $\omega$ to be either 0 (purifying selection) or 1 (neutral selection) fitted the data significantly less well than a selection model $(\ln =-369.81)$ that includes an additional category of sites with $\omega$ estimated from the data $(2 \Delta \mathrm{l}=22.54$, d.f. $1, P<0.0001)$. Out of 57 codons, $96 \%$ were neutral whereas $4 \%$ were in a category with $\omega=43.2$, indicating that the codons are under different selection pressures. This model yielded a very high value for $\omega$, which may be due to the very small number of synonymous mutations in our data. This same reason probably explains why more complex ML models could not be fitted satisfactorily to the data.

\section{Codon usage bias.}

Since only one synonymous mutation was found in NIP 1 , and therefore, purifying selection may be suspected to operate on synonymous codons, several parameters related to codon usage bias were estimated. Codon bias index values ranged from 0.520 to 0.592 , with an average value of 0.553 over 57 codons. Overall G+C content was $0.523,0.580$ at the second position, and 0.458 at the third position. The effective number of codons, which may range from 20 (only one codon used per amino acid) to 61 (all synonymous codons are equally used), was 38.9. All these estimates of codon usage were intermediate between random codon usage and maximum codon bias and did not show an obvious codon usage bias.

\section{Variation in NIP1.}

The DNA sequence coding for NIPl could be sequenced unambiguously for 196 isolates. In addition to the seven previously known NIP1 types (Johnson et al. 1996; Kilby and Robinson 2001; Rohe et al. 1995), 11 new types were identified (Table 2). Some presented new combinations of previously known amino acid changes (types 9 and 11; Table 2), whereas all others presented new mutations. All mutations were point mutations. In type 7 , a mutation $(\mathrm{AG} \rightarrow \mathrm{AA})$ at the acceptor splice site located at the boundary between the intron and the second exon most likely results in aberrant splicing of the pre-mRNA. In type 17 , there was a point mutation that destroyed the start codon. Even though no NIP1 may be expressed from these two types, the amino acid translation was indicated in Table 2 for comprehensiveness. Some sites seemed to be particularly variable (e.g., amino acid 21 of the mature protein, which is located in loop II of the protein [van't Slot et al. 2003]) whereas other regions of the protein were conserved (e.g., amino acids 11 to 20 , which represent the $\mathrm{C}$ terminal half of loop I and $\beta$-strand 2, or amino acids 31 to 41, which form $\beta$-strands 3 and 4 separated by a $\beta$-turn).

Among 196 isolates, none were found that carried NIP1 types 3 to 6 (Table 3 ). Types 1 and 2 were the most common, followed by 11 and 13. Type 1 was found in every region, while type 2 was found in every region except in the Middle East. Type 1 was the most common type in Scandinavia and California, whereas type 2 was the most common type in Australia. Types 11 and 12 were shared between Middle-East and

Table 3. Distribution of NIP1 types and gene diversity in Rhynchosporium secalis from five regions

\begin{tabular}{|c|c|c|c|c|c|c|c|c|c|c|c|c|c|c|c|c|c|}
\hline \multirow[b]{2}{*}{ Region } & \multirow[b]{2}{*}{ Population } & \multicolumn{14}{|c|}{ NIP1 type ${ }^{a}$} & \multirow[b]{2}{*}{$N$} & \multirow{2}{*}{$\begin{array}{c}\text { Gene } \\
\text { diversity }\end{array}$} \\
\hline & & 1 & 2 & 7 & 8 & 9 & 10 & 11 & 12 & 13 & 14 & 15 & 16 & 17 & 18 & & \\
\hline \multirow[t]{11}{*}{ Australia } & RS96AUS1 & & 1 & & & & & & & & & & & & & 1 & \\
\hline & RS96AUS2 & & 3 & & & & & & & & & & & & & 3 & \\
\hline & RS96AUS3 & 2 & 5 & & & & & & & & & & & & & 7 & \\
\hline & RS96AUS4 ${ }^{\mathrm{b}}$ & 1 & 6 & & & & & & & & & & & & & 7 & \\
\hline & RS96AUS5 & 1 & 6 & & & & & & & & & & & & & 7 & \\
\hline & RS96AUS6 $^{\mathrm{b}}$ & 1 & 7 & & & & & & & & 1 & & & & & 9 & \\
\hline & RS96AUS7 & & 7 & & & & & & & & & & & & & 7 & \\
\hline & RS96AUS8 & & 3 & & & & & & & & & & & & & 3 & \\
\hline & RS96AUS10 & 2 & 1 & & & & & & & & & & & & & 3 & \\
\hline & RS96AUST & 1 & 1 & & & & & & & & & & & & & 2 & \\
\hline & Subtotal & 8 & 40 & 0 & 0 & 0 & 0 & 0 & 0 & 0 & 1 & 0 & 0 & 0 & 0 & 49 & 0.31 \\
\hline \multirow[t]{7}{*}{ Middle-East } & RS02JO1 & & & & & & & 8 & & & & & & & & 8 & \\
\hline & RS02JO2 & & & & & & & 8 & & 1 & & & & 7 & & 16 & \\
\hline & RS02SY1 & & & & & & & & & 4 & & & & & & 4 & \\
\hline & RS02SY4 & & & & & & & 1 & & 1 & & & 3 & & & 5 & \\
\hline & RS02SY6 $6^{c}$ & 1 & & & & & & 2 & 2 & 2 & & & 1 & & & 8 & \\
\hline & RS97TR & & & & & & & & & 2 & & & & & & 2 & \\
\hline & Subtotal & 1 & 0 & 0 & 0 & 0 & 0 & 19 & 2 & 10 & 0 & 0 & 4 & 7 & 0 & 43 & 0.71 \\
\hline \multirow[t]{5}{*}{ Scandinavia } & RS96FIF & 4 & 3 & & & & & & & & & & & & & 7 & \\
\hline & RS96NO1N1 & 15 & & & & 7 & 1 & & & & & & & & & 23 & \\
\hline & RS96NO1NK & 4 & & & & 2 & & & 2 & & & & & & & 8 & \\
\hline & RS96SW & & & & & & & 1 & & & & & & & & 1 & \\
\hline & Subtotal & 23 & 3 & 0 & 0 & 9 & 1 & 1 & 2 & 0 & 0 & 0 & 0 & 0 & 0 & 39 & 0.59 \\
\hline California & RS88CAR & 18 & 4 & 0 & 2 & 0 & 0 & 0 & 0 & 0 & 0 & 0 & 0 & 0 & 0 & 24 & 0.40 \\
\hline \multicolumn{18}{|l|}{ Western } \\
\hline \multirow[t]{6}{*}{ Europe } & RS97FR & & 1 & 1 & & & & & & 2 & & & & & & 4 & \\
\hline & RS97DE & & 3 & 4 & & & & & & & & 7 & & & & 14 & \\
\hline & RS97GB & 1 & 6 & & & & & & & & & 3 & & & & 10 & \\
\hline & $\mathrm{RS} 99 \mathrm{CH} 1^{\mathrm{d}}$ & & & 3 & & & & & & 3 & & & & & 1 & 7 & \\
\hline & RS01CH1 & & & 1 & & & & & & 5 & & & & & & 6 & \\
\hline & Subtotal & 1 & 10 & 9 & 0 & 0 & 0 & 0 & 0 & 10 & 0 & 10 & 0 & 0 & 1 & 41 & 0.77 \\
\hline Total & & 51 & 57 & 9 & 2 & 9 & 1 & 20 & 4 & 20 & 1 & 10 & 4 & 7 & 1 & 196 & 0.82 \\
\hline
\end{tabular}


Scandinavian populations and type 13 between Middle-East and Western European populations. The other types were restricted to single populations (types $8,10,14,17$, and 18) or regions (types 7, 9, 15, and 16). One isolate collected from rye in Switzerland and one from barley grass in Australia carried NIP1 types (14 and 18) not found in any other isolates. Distribution of NIP1 isoforms did not differ strikingly between barley and rye or wild grasses populations.

Gene diversity gave a measure of variation within regions (Table 3). All gene diversity values were significantly different from each other, as shown by $t$-tests. Australia and California were the two regions with the lowest gene diversities, 0.31 and 0.40 , respectively. In Australia, only two NIP1 types were found, if we exclude the population collected from barley grass (RS96AUS6) contributing NIP1 type 14. In California, only NIP1 type 8 was found in addition to the two most common types 1 and 2. Gene diversities in the populations from Scandinavia, Western Europe, and the Middle East (0.59, 0.77, and 0.71 , respectively) were higher than those found in Australia and California.

\section{Pathogenicity tests.}

A total of $41 R$. secalis isolates representing 14 different NIP1 isoforms were inoculated on $\operatorname{rrsl}$ (Atlas and Ingrid) and Rrs1 (Atlas 46 and Turk NIL) barley cultivars. Inoculations with the control isolates UK7 (AvrRrsl) and AU2 (avrRrsl) were conducted in each of the four trials, and disease scores were consistent across trials for both isolates on all four barley

Table 4. Disease scores of 41Rhynchosporium secalis isolates representing 14 NIP1 types on the four barley cvs. Atlas, Atlas 46, Ingrid, and Turk NIL

\begin{tabular}{|c|c|c|c|c|c|c|c|}
\hline \multirow[b]{2}{*}{ NIP1 type } & \multirow[b]{2}{*}{ Trial } & \multirow[b]{2}{*}{ Isolate } & \multicolumn{5}{|c|}{ Disease score $^{a}$} \\
\hline & & & Atlas & Atlas 46 & Ingrid & Turk NIL & $N^{\mathrm{b}}$ \\
\hline \multirow[t]{4}{*}{1} & I & UK7 & $0.07 \pm 0.07$ & $0.00 \pm 0.00$ & $\mathbf{4 . 3 6} \pm 0.36$ & $0.00 \pm 0.00$ & 55 \\
\hline & II & UK7 & $0.71 \pm 0.19$ & $0.00 \pm 0.00$ & $\mathbf{5 . 0 0} \pm 0.00$ & $0.07 \pm 0.07$ & 55 \\
\hline & III & UK7 & $0.07 \pm 0.07$ & $0.00 \pm 0.00$ & $\mathbf{5 . 0 0} \pm 0.00$ & $0.00 \pm 0.00$ & 56 \\
\hline & IV & UK7 & $0.00 \pm 0.00$ & $0.00 \pm 0.00$ & $\mathbf{4 . 8 6} \pm 0.10$ & $0.00 \pm 0.00$ & 58 \\
\hline 2 & I & AU1 & $0.00 \pm 0.00$ & $0.00 \pm 0.00$ & $\mathbf{5 . 0 0} \pm 0.00$ & $0.00 \pm 0.00$ & 56 \\
\hline 3 & I & AU3 & $0.00 \pm 0.00$ & $0.00 \pm 0.00$ & $0.07 \pm 0.07$ & $0.15 \pm 0.15$ & 54 \\
\hline \multirow[t]{4}{*}{4} & I & AU2 & $\mathbf{5 . 0 0} \pm 0.00$ & $\mathbf{5 . 0 0} \pm 0.00$ & $\mathbf{4 . 8 0} \pm 0.20$ & $\mathbf{5 . 0 0} \pm 0.00$ & 57 \\
\hline & II & AU2 & $4.73 \pm 0.12$ & $\mathbf{4 . 5 0} \pm 0.34$ & $\mathbf{4 . 7 3} \pm 0.27$ & $\mathbf{5 . 0 0} \pm 0.00$ & 56 \\
\hline & III & AU2 & $\mathbf{5 . 0 0} \pm 0.00$ & $\mathbf{5 . 0 0} \pm 0.00$ & $\mathbf{5 . 0 0} \pm 0.00$ & $\mathbf{5 . 0 0} \pm 0.00$ & 56 \\
\hline & IV & AU2 & $\mathbf{5 . 0 0} \pm 0.00$ & $\mathbf{5 . 0 0} \pm 0.00$ & $\mathbf{4 . 9 3} \pm 0.07$ & $\mathbf{5 . 0 0} \pm 0.00$ & 57 \\
\hline \multirow[t]{3}{*}{7} & II & RS97DE742 & $0.71 \pm 0.22$ & $0.69 \pm 0.17$ & $\mathbf{4 . 8 6} \pm 0.14$ & $\mathbf{5 . 0 0} \pm 0.00$ & 55 \\
\hline & I & RS97DE773 & $0.29 \pm 0.13$ & $0.00 \pm 0.00$ & $\mathbf{5 . 0 0} \pm 0.00$ & $\mathbf{5 . 0 0} \pm 0.00$ & 56 \\
\hline & IV & RS97FR787 & $0.07 \pm 0.07$ & $0.00 \pm 0.00$ & $\mathbf{3 . 5 7} \pm 0.27$ & $\mathbf{4 . 1 4} \pm 0.14$ & 58 \\
\hline \multirow[t]{2}{*}{8} & I & RS88CA27 & $\mathbf{3 . 8 6} \pm 0.33$ & $\mathbf{4 . 7 1} \pm 0.13$ & $\mathbf{3 . 4 3} \pm 0.36$ & $\mathbf{4 . 4 3} \pm 0.25$ & 56 \\
\hline & II & RS88CA27 & $\mathbf{4 . 7 1} \pm 0.16$ & $\mathbf{5 . 0 0} \pm 0.00$ & $\mathbf{5 . 0 0} \pm 0.00$ & $\mathbf{4 . 9 3} \pm 0.07$ & 57 \\
\hline \multirow[t]{3}{*}{9} & II & RS96NO1N1B11 & $0.43 \pm 0.17$ & $0.00 \pm 0.00$ & $\mathbf{5 . 0 0} \pm 0.00$ & $0.00 \pm 0.00$ & 55 \\
\hline & II & RS96NO1N1G43 & $0.14 \pm 0.10$ & $0.00 \pm 0.00$ & $\mathbf{5 . 0 0} \pm 0.00$ & $0.00 \pm 0.00$ & 56 \\
\hline & I & RS96NO1NKD23 & $0.07 \pm 0.07$ & $0.00 \pm 0.00$ & $\mathbf{4 . 9 3} \pm 0.07$ & $0.00 \pm 0.00$ & 54 \\
\hline \multirow[t]{2}{*}{10} & I & RS96NO1N1B41 & $0.07 \pm 0.07$ & $0.00 \pm 0.00$ & $\mathbf{3 . 0 0} \pm 0.36$ & $0.00 \pm 0.00$ & 55 \\
\hline & IV & RS96NO1N1B41 & $0.14 \pm 0.14$ & $0.00 \pm 0.00$ & $\mathbf{5 . 0 0} \pm 0.00$ & $0.00 \pm 0.00$ & 58 \\
\hline \multirow[t]{4}{*}{11} & IV & $\mathrm{RS} 02 \mathrm{JO} 2 \mathrm{H} 2$ & $0.07 \pm 0.07$ & $0.00 \pm 0.00$ & $\mathbf{4 . 5 0} \pm 0.14$ & $0.07 \pm 0.07$ & 58 \\
\hline & IV & RS02SY6-12a & $0.08 \pm 0.08$ & $0.00 \pm 0.00$ & $\mathbf{4 . 5 0} \pm 0.15$ & $0.00 \pm 0.00$ & 49 \\
\hline & IV & RS02SY6-20a & $0.00 \pm 0.00$ & $0.00 \pm 0.00$ & $\mathbf{4 . 0 9} \pm 0.25$ & $0.00 \pm 0.00$ & 48 \\
\hline & I & RS96SWF32 & $0.00 \pm 0.00$ & $0.00 \pm 0.00$ & $\mathbf{3 . 9 3} \pm 0.21$ & $0.53 \pm 0.27$ & 58 \\
\hline \multirow[t]{4}{*}{12} & III & RS02SY6-14a & $0.00 \pm 0.00$ & $0.00 \pm 0.00$ & $\mathbf{4 . 7 1} \pm 0.13$ & $0.07 \pm 0.07$ & 56 \\
\hline & III & RS02SY6-30a & $0.07 \pm 0.07$ & $0.00 \pm 0.00$ & $\mathbf{5 . 0 0} \pm 0.00$ & $0.00 \pm 0.00$ & 55 \\
\hline & II & RS96NO1NKG11 & $0.36 \pm 0.17$ & $0.00 \pm 0.00$ & $\mathbf{5 . 0 0} \pm 0.00$ & $0.00 \pm 0.00$ & 55 \\
\hline & I & RS96NO1NKI11 & $0.07 \pm 0.07$ & $0.00 \pm 0.00$ & $\mathbf{4 . 5 3} \pm 0.13$ & $0.00 \pm 0.00$ & 59 \\
\hline \multirow[t]{6}{*}{13} & II & RS01CH1A14a.1 & $0.29 \pm 0.16$ & $0.00 \pm 0.00$ & $\mathbf{5 . 0 0} \pm 0.00$ & $0.00 \pm 0.00$ & 56 \\
\hline & I & RS01CH1B3a & $0.29 \pm 0.22$ & $0.00 \pm 0.00$ & $4.73 \pm 0.15$ & $0.00 \pm 0.00$ & 53 \\
\hline & II & RS01CH1B9a & $0.00 \pm 0.00$ & $0.00 \pm 0.00$ & $\mathbf{4 . 7 1} \pm 0.16$ & $0.00 \pm 0.00$ & 56 \\
\hline & II & RS97FR784 & $0.00 \pm 0.00$ & $0.00 \pm 0.00$ & $\mathbf{5 . 0 0} \pm 0.00$ & $0.00 \pm 0.00$ & 56 \\
\hline & I & RS97FR785 & $0.00 \pm 0.00$ & $0.07 \pm 0.07$ & $\mathbf{4 . 9 2} \pm 0.08$ & $0.00 \pm 0.00$ & 56 \\
\hline & II & RS97TR737 & $2.43 \pm 0.63$ & $0.00 \pm 0.00$ & $\mathbf{4 . 3 6} \pm 0.20$ & $0.00 \pm 0.00$ & 56 \\
\hline \multirow[t]{3}{*}{15} & I & RS97DE684 & $0.00 \pm 0.00$ & $0.00 \pm 0.00$ & $\mathbf{4 . 6 9} \pm 0.24$ & $0.00 \pm 0.00$ & 50 \\
\hline & II & RS97DE711 & $1.00 \pm 0.32$ & $0.00 \pm 0.00$ & $\mathbf{5 . 0 0} \pm 0.00$ & $0.00 \pm 0.00$ & 56 \\
\hline & II & RS97GB693 & $1.07 \pm 0.32$ & $0.00 \pm 0.00$ & $\mathbf{5 . 0 0} \pm 0.00$ & $0.00 \pm 0.00$ & 59 \\
\hline \multirow[t]{3}{*}{16} & III & RS02SY4-41a & $0.21 \pm 0.15$ & $0.00 \pm 0.00$ & $\mathbf{5 . 0 0} \pm 0.00$ & $0.07 \pm 0.07$ & 56 \\
\hline & III & RS02SY4-58a & $0.00 \pm 0.00$ & $0.00 \pm 0.00$ & $\mathbf{5 . 0 0} \pm 0.00$ & $0.00 \pm 0.00$ & 56 \\
\hline & IV & RS02SY6-28a & $0.07 \pm 0.07$ & $0.29 \pm 0.19$ & $4.73 \pm 0.14$ & $\mathbf{5 . 0 0} \pm 0.00$ & 52 \\
\hline \multirow[t]{4}{*}{17} & IV & RS02JO2A1 & $0.00 \pm 0.00$ & $0.29 \pm 0.29$ & $4.29 \pm 0.16$ & $\mathbf{4 . 5 7} \pm 0.14$ & 57 \\
\hline & III & RS02JO2C3 & $0.00 \pm 0.00$ & $0.00 \pm 0.00$ & $\mathbf{3 . 9 3} \pm 0.37$ & $4.36 \pm 0.13$ & 56 \\
\hline & IV & RS02JO2D3 & $0.00 \pm 0.00$ & $0.07 \pm 0.07$ & $\mathbf{4 . 5 4} \pm 0.14$ & $\mathbf{4 . 4 7} \pm 0.17$ & 57 \\
\hline & IV & RS02JO2E9 & $0.00 \pm 0.00$ & $0.07 \pm 0.07$ & $\mathbf{5 . 0 0} \pm 0.00$ & $4.93 \pm 0.07$ & 58 \\
\hline \multirow[t]{4}{*}{ Deletion } & III & RS01ET1A10a & $0.00 \pm 0.00$ & $0.00 \pm 0.00$ & $3.79 \pm 0.35$ & $\mathbf{4 . 5 7} \pm 0.17$ & 56 \\
\hline & III & RS01ET1A1b & $0.00 \pm 0.00$ & $0.00 \pm 0.00$ & $\mathbf{5 . 0 0} \pm 0.00$ & $\mathbf{4 . 7 9} \pm 0.11$ & 57 \\
\hline & III & RS88CA14 & $0.36 \pm 0.36$ & $0.36 \pm 0.25$ & $\mathbf{4 . 3 6} \pm 0.29$ & $4.29 \pm 0.24$ & 56 \\
\hline & IV & RS88CA157 & $0.00 \pm 0.00$ & $0.08 \pm 0.08$ & $2.00 \pm 0.43$ & $4.69 \pm 0.13$ & 52 \\
\hline \multirow[t]{4}{*}{$\mathrm{H}_{2} \mathrm{O}$} & I & $\mathrm{H} 2 \mathrm{O}$ & $0.14 \pm 0.10$ & $0.00 \pm 0.00$ & $0.00 \pm 0.00$ & $0.00 \pm 0.00$ & 56 \\
\hline & II & $\mathrm{H} 2 \mathrm{O}$ & $0.86 \pm 0.14$ & $0.46 \pm 0.14$ & $0.71 \pm 0.13$ & $0.57 \pm 0.14$ & 55 \\
\hline & III & $\mathrm{H} 2 \mathrm{O}$ & $0.20 \pm 0.11$ & $0.07 \pm 0.07$ & $0.27 \pm 0.15$ & $0.00 \pm 0.00$ & 60 \\
\hline & IV & $\mathrm{H} 2 \mathrm{O}$ & $0.00 \pm 0.00$ & $0.00 \pm 0.00$ & $0.00 \pm 0.00$ & $0.00 \pm 0.00$ & 51 \\
\hline
\end{tabular}

${ }^{a}$ Disease scores (DS) according to Reitan et al. 2002, shown as averages ( \pm standard error). DS $\leq 2$ indicates a resistant reaction; $2<$ DS $\leq 3$, moderately resistant; $3<\mathrm{DS} \leq 4$, moderately susceptible; and DS $>4$, susceptible. DS $>3$ are in bold.

${ }^{\mathrm{b}} \mathrm{N}$ is the number of plants scored. 
cultivars (Table 4). This indicates that results were reproducible and that all trials were successful. AU2 and RS88CA27 (type 8 ) were the only two isolates able to cause disease on Atlas or on Atlas 46. All isolates could infect Ingrid, except AU3, which may have lost pathogenicity through repeated in vitro transfers. The two isolates virulent on Atlas 46 were able to infect Turk NIL. Additionally, isolates carrying NIP1 type 7 or 17 and isolates lacking NIPl were also able to overcome the resistance in Turk NIL. One isolate carrying NIP1 type 16 was able to infect Turk NIL, while the other two isolates carrying the same NIP1 type were not. However, this isolate died in silica gel storage, preventing any verification of this result.

\section{Field experiment.}

A field experiment was conducted in Chico and Davis, California, with two adjacent plots planted to Atlas and Atlas 46 to examine the selection effect of Rrsl on the R. secalis population. DNA samples were extracted from potentially infected leaf material, and amplification of the mating type idiomorphs was used to detect the presence of $R$. secalis DNA. Among the leaves collected from Atlas 46 in Chico, $R$. secalis DNA could be detected in only one out of 33 samples. From leaves collected at Davis, on the other hand, $R$. secalis DNA could be amplified from 30 and 50 samples collected from Atlas and Atlas 46, respectively (Table 5). The NIP1 gene could be amplified from 28 samples from Atlas but from none of the samples from Atlas 46. This significant difference $\left(\chi^{2}=71.79, P<\right.$ 0.001 ) indicates that deletion of the NIPl gene in $R$. secalis growing on Atlas 46 was the cause of virulence on the Rrsl barley cultivar.

\section{DISCUSSION}

The two main mechanisms leading to virulence at the NIPI locus in $R$. secalis were examined. We assessed deletion frequency and diversity at the molecular level for this fungal avirulence gene. From sequence data, amino acid sequences were inferred, and pathogenicity of the different types found was tested. We found that some of these isoforms were restricted to certain geographical regions. These data may contribute to a better understanding of the mechanisms (deletions and alteration of avirulence genes by point mutations) that lead to resistance breakdown in agroecosystems.

Deletion of NIP1 was much more frequent than that of NIP2 and NIP3. These latter two genes encode proteins that, like NIP1, induce necrosis in barley but, according to current knowledge, do not function as elicitors (Hahn et al. 1993). Therefore, the high deletion frequency observed for NIPl may be attributed to its elicitor function and to the selection of $R$. secalis isolates lacking NIPl by cultivation of $\operatorname{Rrs} l$ barley varieties.

NIPI deletion frequency varied considerably among the populations studied, suggesting a heterogeneous use of Rrsl by breeders. In Ethiopia, all isolates lacked NIP1. Because of the high gene diversity found in these populations with restric- tion fragment length polymorphisms (RFLP) (P. Zaffarano, C. C. Linde, and B. A. McDonald, unpublished data), a founder effect can be excluded. Therefore, we hypothesize that the widespread NIPl deletion is due to a past or present widespread distribution of the Rrs 1 resistance gene. The Ethiopian barley landraces were shown to be distinct from those of other countries (Bjørnstad et al. 1997), which implies that the $R$. secalis populations are also likely to be different. Ethiopian $R$. secalis strains were virulent on Ethiopian landraces (Yitbarek et al. 1998), but Californian isolates were avirulent on these same landraces (Webster et al. 1980), supporting the distinctness of the Ethiopian population of $R$. secalis.

On the other hand, populations were found in which all isolates had NIP1, and even more interesting, populations were found in which isolates with NIPl coexisted with isolates lacking the gene. This coexistence indicates that the fitness cost of NIPI deletion cannot be very high, otherwise isolates with NIPl would rapidly be positively selected and NIPI would become fixed. This hypothesis was corroborated by experiments showing only a slight decrease in virulence of a mutant strain in which the NIPl gene had been replaced through homologous recombination (W. Knogge, unpublished data). In contrast, replacement of NIP3 resulted in a much greater loss of virulence (W. Knogge, unpublished data). The Californian population, which contains isolates with and without NIP1, was collected from a barley composite cross (McDonald et al. 1989). There, some of the parental cultivars may have contained Rrsl, which may still be present in some of the barley plants, creating a heterogeneous selection pressure that could have maintained the polymorphism in the $R$. secalis population.

Deletion of NIPI was the only mechanism found for virulence in the California field experiment with naturally infected Atlas and Atlas 46. All of the samples from Atlas 46 were lacking NIP1. In this same area, a population had been collected in 1988, and as mentioned above, some isolates were already lacking NIP1. This suggests that isolates without NIPI may already have been present in this region and increased in frequency on Atlas 46.

The study of the second mechanism for gaining virulence, i.e., alteration of the avirulence gene by point mutations, required an analysis of DNA polymorphism. Often, nucleotide diversity is not constant across the different regions of a gene. Because introns do not have any apparent function, they are expected to evolve more rapidly and, consequently, to show a higher nucleotide diversity than exons or 5' flanking regions (MacIntyre 1985). Analysis of variation in the NIPl gene showed that nucleotide diversity was not constant across the different gene regions and was unexpectedly about four times higher in the region coding for the main part of the mature protein than in any other region. This increased variation in the sequence coding for the main part of mature NIP1 hints at positive diversifying selection. However, tests for neutrality of mutations did not detect selection acting on the whole DNA sequence, but these tests are conservative (Ford 2002). On the

Table 5. Polymerase chain reaction amplification of the mating type idiomorphs (MAT1-1, MAT1-2) and of the NIP1 gene in 80 DNA samples ${ }^{\mathrm{a}}$

\begin{tabular}{|c|c|c|c|c|c|}
\hline \multirow[b]{2}{*}{ MAT1 amplicon } & \multirow[b]{2}{*}{$N^{\mathbf{b}}$} & \multicolumn{2}{|c|}{ Atlas } & \multicolumn{2}{|c|}{ Atlas 46} \\
\hline & & NIP1 absent & NIP1 present & NIP1 absent & NIP1 present \\
\hline None & 39 & & & & \\
\hline MAT1-1 & 3 & 0 & 3 & 0 & 0 \\
\hline$M A T 1-2$ & 49 & 2 & 23 & 24 & 0 \\
\hline$M A T 1-1$ and $M A T 1-2$ & 28 & 0 & 2 & 26 & 0 \\
\hline Total & $80^{c}$ & 2 & 28 & 50 & 0 \\
\hline
\end{tabular}

${ }^{a}$ Obtained from diseased leaf material collected from two barley cultivars, Atlas and Atlas 46, in Davis, California.

${ }^{\mathrm{b}}$ Number of DNA samples analyzed for MAT1 amplification.

${ }^{c}$ Total excluding samples for which MAT1 did not amplify. 
other hand, the evolutionary pathway method showed that there was an excess of nonsynonymous mutations in the sequence coding for the mature NIP1. The ML method confirmed that NIPl is under positive diversifying selection.

The neutral theory of molecular evolution proposes that the vast majority of mutations are neutral or deleterious (Kimura 1983). The recent accumulation of sequence data allowed a test of this theory, and the proportion of genes under positive diversifying selection may be larger than predicted by the neutral theory (Ford 2002). An increasing number of genes or proteins have been shown to be under positive selection (Wolfe and $\mathrm{Li}$ 2003). Most of them are involved in male or female reproduction, defense systems, or immunity or in evading defense systems or immunity. In this latter group, many proteins from pathogenic microbes are found that are possibly used as targets by the host immune or defense system. Most relevant to this study, several plant resistance genes were shown or are suspected to evolve in response to positive selection (Stahl and Bishop 2000). A report on cell wall degrading enzymes produced by pathogens and their host plant-produced inhibitors indicated that both types of protein are under positive selection and illustrates the arms race going on between plant and pathogens (Stotz et al. 2000). The coevolution between these enzymes and their inhibitors could be similar to the coevolution between resistance genes and their corresponding avirulence genes.

Since selection does not act on genotypes but rather on phenotypes and since NIPl encodes a protein with two functions-NIP1 is an elicitor and a toxin-one may ask which one of these two functions is driving positive diversifying selection. One hypothesis is that positive selection is acting to slightly modify the protein, thus preventing its recognition by plant receptors without impeding its toxin function. Does this hypothesis hold when confronted with the actual knowledge on NIP1 mode of action?

The plant receptor to which NIP1 binds has not yet been isolated, but a high-affinity NIP1-binding site was recently detected in membranes of barley, irrespective of the resistance genotype (K. A. E. van't Slot and W. Knogge, unpublished data). Furthermore, NIP1 has been shown to stimulate the activity of the $\mathrm{H}^{+}$-ATPase in plasma membranes from resistant and susceptible plants (Wevelsiep et al. 1993). The two virulent NIP1 types 3 and 4 carry two amino acid alterations that turn them into ineffective elicitors (compatible interaction), but these two types also do not activate the $\mathrm{H}^{+}$-ATPase and do not cause leaf necrosis (Fiegen and Knogge 2002). It was therefore suggested that both NIP1 functions are mediated through a single receptor and that the signaling pathway branches downstream to lead to the two functions of the protein (Knogge et al. 1999). The receptor is therefore most likely not encoded by the Rrsl resistance gene (Fiegen and Knogge 2002), and a model assuming direct binding of the elicitor to a receptor encoded by the resistance gene is unlikely. More complex models partly inspired by the "guard hypothesis" (Van der Biezen and Jones 1998) have been proposed (van't Slot 2002). These findings of the linkage between the elicitor and the toxin functions do not support the hypothesis of positive diversifying selection acting to modify NIP1 to avoid its recognition by the plant while simultaneously retaining its toxin function.

Among the many amino acid mutations observed in NIP1, only a few (probably three, one for each of the three virulent types, excluding types 7 and 17, which most likely gain virulence through nonexpression) lead to virulence on Rrsl barley cultivars, and it is plausible to believe that these mutations were retained by positive diversifying selection. However, all the other mutations did not affect virulence. These mutations may have been successful at evading recognition in earlier host populations (including wild barley progenitors), but in the meantime, new cultivars were bred with other recognition strategies. Knowledge of the effect of the mutation in the virulent type 8 and of the other mutations on the toxicity of the different NIP1 isoforms may increase understanding of the ecological meaning of positive diversifying selection. A better understanding of the biochemical pathways in which NIP1 is involved may also shed more light on the selection process.

All but two of the isolates could not infect Atlas but were virulent on Ingrid. This could be explained by the fact that Atlas contains the resistance gene $R h 2$ (Goodwin et al. 1990) and that these isolates could not overcome this resistance. In our study, the reaction of Atlas upon inoculation with isolate UK7 was scored as incompatible. This contradicts previous data that considered UK7 as being virulent on Atlas (Lehnackers and Knogge 1990). However, the Atlas seed used in the present study was not obtained from the same source and the Atlas and Atlas 46 accessions may be heterogeneous. UK7 was virulent on Ingrid, which is thought not to contain any resistance genes. In general, the near-isogenic cultivar pair Ingrid-Turk NIL seemed more appropriate to test for the ability of the different NIP1 types to overcome Rrsl resistance, since Turk NIL probably contains only this resistance gene (Bjørnstad et al. 2002). In this respect, isolates carrying NIP1 types 5 and 6 , which were avirulent on Atlas and Atlas 46 (Kilby and Robinson 2001), should probably also be inoculated on Ingrid and Turk NIL.

In addition to isolates carrying NIP1 isoforms 3 and 4, four classes of isolates were able to avoid detection by the Rrs 1 resistance gene: the isolates with NIPl deletions and those with NIP1 types 7, 8, or 17 . Virulence of types 7 and 17 is most likely due to the nonexpression of NIP1 in the isolates carrying this type. Two isolates with NIP1 type 7 were previously collected from Atlas 46 (Johnson et al. 1996). Virulence of NIP1 type 8 may be attributed to a mutation from tyrosine to phenylalanine at amino acid 44, which is located in loop III of the protein in the same region as the inactivating mutation in type 4 at amino acid 45 (Rohe et al. 1995; van't Slot et al. 2003).

The only virulent NIP1 types that were found in this study were types 7, 8, and 17. Even though types 3 and 4 were previously observed in Australia (Rohe et al. 1995), we did not find these types among the 49 Australian isolates we sequenced. Isolates carrying the virulent type 7 were found in different Western European countries, including France, Germany, and Switzerland. Isolates carrying NIP1 type 8 were found only in the Californian population, and isolates carrying type 17 were found only in one of the Jordanian populations (RS02JO2). Since each of the virulent NIP1 types was restricted to a population or at most to a region, we can hypothesize that virulence arose independently three times.

Variation in NIP1 types within regions was measured with gene diversity. Gene diversity was the lowest in Australia. Diversity for isozyme and RFLP loci were also lower in Australian than in Scandinavian $R$. secalis populations (Goodwin et al. 1993; Salamati et al. 2000), and it was suggested that the low diversity in the Australian population is the result of a founder event (Salamati et al. 2000). The low diversity in the Californian population may be due to the small spatial scale over which isolates were collected and to the small sample size compared with other regions.

NIP1 types 1 and 2 were by far the most common types found. However, type 2 stimulates the $\mathrm{H}^{+}$-ATPase less than type 1 and causes only chlorotic (instead of necrotic) lesions, indicating a weaker toxicity (Fiegen and Knogge 2002). If higher toxicity is correlated with higher fitness, one would 
expect isolates carrying type 1 to have a fitness advantage over isolates carrying type 2 and, therefore, to be more frequent. This was not the case in the regions surveyed. Overall both types were equally common. In two regions (Scandinavia and California), type 1 was more frequent, whereas type 2 was more frequent in two other regions (Australia and Western Europe). Our interpretation is that either a higher toxicity does not confer higher fitness or the fitness advantage is too small to lead to detectable differences in frequency.

Gain of virulence on $\operatorname{Rrs} 1$ cultivars was achieved in two ways: through deletion of NIPl and through point mutations in this avirulence gene. Virulence due to altered NIPl seems to have arisen independently at least three times, in California, Western Europe, and Jordan. However, these mutations were observed in only 18 out of 196 isolates $(9 \%)$. The finding of positive diversifying selection acting on NIPl suggests that diversifying selection operating at resistance gene loci in plants leads to diversifying selection for corresponding avirulence gene loci in plant pathogens. On the other hand, deletion of NIPl appears to be a more common mechanism for gaining virulence, with $45 \%$ of the isolates lacking NIP1. This high proportion may be due to the irreversible character of deletions, and the high frequency suggests that there is either a low or no fitness cost associated with NIPl deletion. In addition, if mutated NIP1 proteins that lost the elicitor function are also nonfunctional toxins, the deletion mechanism may offer an advantage over the point mutation mechanism, since the production of a mutated NIP1 would involve the cost of synthesizing the protein but no benefit.

\section{MATERIALS AND METHODS}

\section{Origin of $\boldsymbol{R}$. secalis isolates.}

$R$. secalis isolates collected in Australia, Ethiopia, Finland, Norway, Switzerland, and California were described previously (Table 6). Populations were collected from naturally infected barley fields along one or more transects or using a hierarchical sampling strategy (McDonald et al. 1999). Additional Australian isolates were collected from barley grass (Hordeum leporinum Link) on plants bordering two of the barley fields (populations 4 and 6). In Norway in the early 1990s, isolates were collected from different fields and locations at random. In 1997, single isolates were collected from fields in France, Germany, Great Britain, and Turkey from different barley cultivars. A hierarchical collection was made in 1996 from an unknown barley variety in Sweden. In Jordan, two hierarchical collections were made $2 \mathrm{~km}$ apart, in Al-Raba in 2002. Three collections were made in the north of Syria in 2002. The first population was collected in a barley field near the village of Batajik in the Al Bab-Aleppo province, and the second col-

Table 6. Country of origin, host species, host cultivar, and sampling scheme of the R. secalis populations used in the present study

\begin{tabular}{|c|c|c|c|c|c|c|}
\hline Country & Population & Code $^{a}$ & Host & Cultivar & Sampling & Reference or source \\
\hline \multirow{10}{*}{ Australia } & 1 & RS96AUS1 & Barley & Clipper & Hierarchical & McDonald et al. 1999 \\
\hline & 2 & RS96AUS2 & Barley & Clipper & Hierarchical & McDonald et al. 1999 \\
\hline & 3 & RS96AUS3 & Barley & O'Connor & Hierarchical & McDonald et al. 1999 \\
\hline & 4 & RS96AUS4 & Barleygrass & & Random & $\begin{array}{l}\text { From plants bordering } \\
\text { RS96AUS3 field }\end{array}$ \\
\hline & 5 & RS96AUS5 & Barley & Schooner & Hierarchical & McDonald et al. 1999 \\
\hline & 6 & RS96AUS6R, X & Barleygrass & & Transects & $\begin{array}{l}\text { From plants bordering } \\
\text { RS96AUS5 field }\end{array}$ \\
\hline & 7 & RS96AUS7 & Barley & Arapollis & Hierarchical & McDonald et al. 1999 \\
\hline & 8 & RS96AUS8 & Barley & Stirling & Hierarchical & McDonald et al. 1999 \\
\hline & 9 & RS96AUS10 & Barley & Yerong & Transects & McDonald et al. 1999 \\
\hline & 10 & RS96AUST & Barley & Tantagara & "Hot-spot" & McDonald et al. 1999 \\
\hline \multirow[t]{4}{*}{ Ethiopia } & 1 & RS01ET1 & Barley & Local barley landrace (LR) & Hierarchical & Linde et al. 2003 \\
\hline & 2 & RS01ET2 & Barley & Local barley LR & Hierarchical & Linde et al. 2003 \\
\hline & 3 & RS01ET3 & Barley & Local barley LR & Hierarchical & Linde et al. 2003 \\
\hline & 4 & RS01ET4 & Barley & Local barley LR & Hierarchical & Linde et al. 2003 \\
\hline Finland & & RS96FIF & Barley & Kymppi & Hierarchical & Salamati et al. 2000 \\
\hline France & & RS97FR & Barley & Systel, Marilor, Maeva & Random & J. Speakman \\
\hline Germany & & RS97DE & Barley & Danilo, Caraibe, Rocca & Random & J. Speakman \\
\hline Great Britain & & RS97GB & Barley & Maris Otter, Gaelic, Pipkin & Random & J. Speakman \\
\hline \multirow[t]{2}{*}{ Jordan } & 1 & RS02JO1 & Barley & Unknown & Hierarchical & K. Meles \\
\hline & 2 & RS02JO2 & Barley & Unknown & Hierarchical & K. Meles \\
\hline \multirow[t]{3}{*}{ Norway } & 1 & RS90sNO & Barley & Unknown & Random & S. Salamati \\
\hline & 2 & RS96NO1N1 & Barley & Tyra & Hierarchical & Salamati et al. 2000 \\
\hline & 3 & RS96NO1NK & Barley & Tyra & Hierarchical & Salamati et al. 2000 \\
\hline Sweden & & RS96SW & Barley & Unknown & Hierarchical & S. Salamati \\
\hline \multirow[t]{7}{*}{ Switzerland } & 1 & RS99CH1 & Rye & Danko & Hierarchical & B.A. McDonald \\
\hline & 2 & RS99CH2 & Barley & Unknown & Hierarchical & Linde et al. 2003; Collection 1 \\
\hline & 3 & RS99CH5 & Barley & $\begin{array}{l}\text { Mixture of } 2 \text { two -row } \\
\text { varieties }\end{array}$ & Hierarchical & Linde et al. 2003; Collection 2 \\
\hline & 4 & RS99CH6 & Barley & Two-row variety & Hierarchical & Linde et al. 2003; Collection 3 \\
\hline & 5 & RSOOCH & Barley & Unknown & Hierarchical & Linde et al. 2003; Collection 4 \\
\hline & 6 & RS01CH1 & Barley & Baretta & Transects & Linde et al. 2003; Collection 5 \\
\hline & 7 & RS01CH2 & Barley & Unknown & Transects & Linde et al. 2003; Collection 6 \\
\hline \multirow[t]{4}{*}{ Syria } & 1 & RS02SY1 & Barley & Rihane & Transects & B. A. McDonald and C. C. Linde \\
\hline & 2 & RS02SY4 & Barley & Arabi Aswad & Transects & B. A. McDonald and C. C. Linde \\
\hline & 3 & RS02SY6 & Hordeum & & & \\
\hline & & & spontaneum & & Random & B. A. McDonald and C. C. Linde \\
\hline Turkey & & RS97TR & Barley & Unknown & Random & J. Speakman \\
\hline California, U.S.A. & & RS88CAR & Barley & CC II and V & Hierarchical & McDonald et al. 1989 \\
\hline
\end{tabular}

${ }^{a}$ A code is assigned to each population. The first two letters of the code (RS) stand for the organism, $R$. secalis, and the two numbers following describe the year of the collection. Then, two or three letters stand for the country where the collection was made, and the last number indicates the different populations collected in that particular year and country. For instance, RS96AUS3 refers to the third R. secalis population collected in 1996 in Australia. 
lection was made from the local barley landrace Arabi Aswad near the village of Al Jurn Al Aswad in the Raqqa province; both are located along transects. The third population was collected from Hordeum spontaneum growing in a field planted to cumin near the village of Aim Issa. In Switzerland, population 1 was collected from an organic rye field. Populations were grouped into five regions (Table 3). Isolations were made from plant leaves, as described in McDonald and associates (1999), and DNA was extracted as described in that paper or as described in Linde and associates (2003). A subset of these populations (Table 1) was used to detect the presence of the three NIP genes, and another partially overlapping subset (Table 3 ) was used to study the variation in the NIPl gene. Isolates identified as distinct genotypes with RFLP were chosen from these populations for sequencing.

\section{Hybridization of the NIP1, NIP2, and NIP3 genes.}

For each gene, a probe was generated with polymerase chain reaction (PCR). The probes were labeled with ${ }^{32} \mathrm{P}$, using nick translation (Invitrogen Corporation, Carlsbad, CA, U.S.A.) and were hybridized to Southern blots with DNA of $R$. secalis isolates. Primers designed by Kilby and Robinson (2001) were used to amplify the NIP1 gene. For NIP2 and NIP3, primers were designed based on the sequences of these two genes (W. Knogge, unpublished data). Each PCR mix (final volume $60 \mu \mathrm{l}$ ) contained $0.5 \mu \mathrm{M}$ of each primer, $100 \mu \mathrm{M}$ of each nucleotide, 6 $\mu \mathrm{l}$ of $10 \times$ PCR buffer $\left(500 \mathrm{mM} \mathrm{KCl}, 15 \mathrm{mM} \mathrm{MgCl}_{2}\right.$, and 100 $\mathrm{mM}$ Tris- $\mathrm{HCl}[\mathrm{pH} 9.0])$, and $1.5 \mathrm{U}$ of $\mathrm{Taq}$ DNA polymerase (Amersham Biosciences, Europe $\mathrm{GmbH}$, Otelfingen, Switzerland). The following cycling conditions were employed: initial denaturation for $2 \mathrm{~min}$ at $96^{\circ} \mathrm{C}$, followed by 30 cycles of denaturation for $1 \mathrm{~min}$ at $96^{\circ} \mathrm{C}$, annealing for $1 \mathrm{~min}$ at $64^{\circ} \mathrm{C}$, and elongation for $1 \mathrm{~min} 30 \mathrm{~s}$ at $72^{\circ} \mathrm{C}$, followed by a final elongation step of $10 \mathrm{~min}$ at $72^{\circ} \mathrm{C}$. The PCR products were purified using a multiscreen PCR plate MANU 030 PCR (Millipore, Billerica, MA, U.S.A.). When a probe did not bind to any DNA fragment of a particular isolate, the gene in question was considered to be deleted in this isolate only after ensuring that other probes bound to this DNA digest. Otherwise, this datum point was excluded.

For all populations except the one from Norway, the data were clone-corrected with RFLP data collected previously (McDonald et al. 1999, B. A. McDonald unpublished data, P. Zaffarano, unpublished data and). Seven single-locus probes and one multicopy probe were used to detect clones (McDonald et al. 1999). We applied tests of linkage disequilibrium in Popgene version 1.32 (Yeh et al. 1999). A two-locus linkage disequilibrium test (Weir 1979) was used to test for linkage disequilibria between pairs of loci, and a multilocus test based on the number of heterozygous loci between two randomly chosen isolates in a population (Brown et al. 1980) was applied.

\section{Variation in the NIP1 gene.}

Based on the sequence of NIP1 (U20363) in the GenBank sequence database, primers were designed to amplify and sequence four fragments spanning the entire known sequence (Table 7). PCR conditions were as above, except for the annealing temperature, which was $65^{\circ} \mathrm{C}$, and a 1 -min elongation step. Some of the purified PCR products were sequenced using a Beckman Coulter CEQ 2000 dye terminator cycle sequencing kit with both the forward and reverse primers on a Beckman Coulter CEQ 2000 automated sequencer (Beckman Coulter, Fullerton, CA, U.S.A.), according to the manufacturer's instructions. Amplicons were purified on Sephadex G-50 fine DNA grade resin columns on a multiscreen HV plate (Millipore). Other PCR products were sequenced with ABI PRISM BigDye Terminator v3.0 and 3.1 ready reaction cycle sequencing kit (Applied Biosystems, Foster City, CA, U.S.A.). Each reaction contained $1 \mu \mathrm{l}$ ready reaction mix, $1.5 \mu \mathrm{l} 5 \times$ reaction buffer (400 mM Tris-HCL, pH 9.0, 10mM $\mathrm{MgCl}_{2}$ ), $1 \mu \mathrm{M}$ primer, 3 to $10 \mathrm{ng}$ PCR product, and water up to $10 \mu \mathrm{l}$. The cycle sequencing conditions were according to the manufacturer's

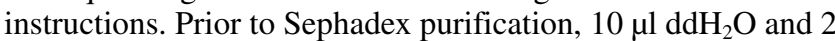
$\mu \mathrm{l} 2.2 \%$ sodium dodecyl sulfate were added to the reactions, and samples were heated at $98^{\circ} \mathrm{C}$ for $5 \mathrm{~min}$. These samples were analyzed on a $3100 \mathrm{ABI}$ automated sequencer.

\section{Sequence analysis.}

For each isolate, sequences obtained with forward and reverse primers were aligned and edited manually with $\mathrm{Se}$ quencher 4.1 (Gene Codes Corporation, Ann Arbor, MI, U.S.A.). The same software was used to align sequences from different isolates. DnaSP version 3.53 (Rozas and Rozas 1999) was used to calculate nucleotide diversity and to perform tests of neutral evolution.

The 1,524-bp-long sequence including the NIPI gene was divided into seven distinct regions. The $5^{\prime}$ flanking region ranged from sites -967 to -90 . The $5^{\prime}$ untranslated region was defined as starting at the most $5^{\prime}$ transcription start site (-89) mentioned in Rohe and associates (1995). The signal peptide (sites 1 to 66), the remainder of the first exon (67 to 237), the intron (238 to 303 ), and the second exon (304 to 312 ) were as described previously (Rohe et al. 1995). The entire region $3^{\prime}$ of the last exon (313 to 557) was called the $3^{\prime}$ flanking region, since no polyadenylation signal and therefore no $3^{\prime}$ untranslated region could be identified.

\section{Tests of neutral selection.}

Different approaches were used to test for neutral selection. First, Tajima's D (Tajima 1989) and Fu and Li's F* and D* test statistics ( $\mathrm{Fu}$ and $\mathrm{Li} \mathrm{1993)}$ were applied. These tests are based on differences between estimates of nucleotide polymorphism. The three test statistics were calculated for all sequences and also separately for each of the five regions.

Second, methods based on comparisons of synonymous $\left(d_{S}\right)$ and nonsynonymous $\left(d_{N}\right)$ substitution rates were used. Only the part of the first exon coding for the mature NIP1 was used for this analysis, since the signal peptide showed too little polymorphism for a meaningful statistical analysis and the second exon was only three codons long and conserved. The analyses were conducted with the 13 haplotypes found among the studied isolates and with two sequences obtained from isolates AU2 and AU3 (Rohe et al. 1995), representing two haplotypes not found in this study. The ratio between $d_{N}$ and $d_{S}, \omega$, indicates which selection pressure is acting on the gene under consideration. If purifying selection removes nonsynonymous mutations, $\omega$ will be $<1$. If nonsynonymous mutations are neu-

Table 7. Oligonucleotides used for PCR amplification of the NIP1 gene

\begin{tabular}{lll}
\hline Fragment & \multicolumn{1}{c}{ Forward primer $\mathbf{5}^{\prime} \mathbf{\rightarrow} \mathbf{3} \mathbf{\prime}$} & \multicolumn{1}{c}{ Reverse primer 5' $\boldsymbol{\rightarrow} \mathbf{3}$} \\
\hline 1 & NIP1_21F AATTCGACGCTGCTCATTGG & NIP1_441R CGCACCCAGAACGGCCAAGC \\
2 & NIP1_380F AGCCTTGCAGCAGGAGCAC & NIP1_802R CCTGTGGATGGGCAATGG \\
3 & NIP1_801F GGTTTCCAGGATAATTAAGCC & NIP1_1200R AGCCATTGCCACCTTCAC \\
4 & NIP1_1117F AGCTCTCAAAGCTGTTTCCG & NIP1_1558R GCCACGATAGATAGTATATGAATTGC \\
\hline
\end{tabular}


tral, they will be fixed at the same rate as synonymous mutations and $\omega$ will be $=1$ (Kimura 1983). If nonsynonymous mutations are beneficial, they will be retained by positive diversifying selection and $\omega$ will be $>1$. First, we used an evolutionary pathway method to estimate $d_{S}$ and $d_{N}$, and computed these values according to Nei and Gojobori (1986) with the Jukes and Cantor correction (1969) for all pairwise comparisons and over all sequences with MEGA2 (Kumar et al. 2001). A $t$-test was conducted with overall $d_{N}$ and $d_{S}$ and their bootstrap variance (Hughes and Nei 1988), to test whether $\omega$ is greater than one. Since this test is prone to type I error (Zhang et al. 1997), the critical value was raised to $t>2.2$, which, even if biased, corresponds to $P<0.05$ (Bishop et al. 2000). Second, we used a ML method to calculate $d_{S}$ and $d_{N}$. Using the CODEML program in the PAML package (Yang 1997), three codon-based models were applied to the data: i) a one-ratio model that assumes one category for $\omega$, which was then either estimated from the data or fixed at one (all mutations are neutral), ii) a neutral model in which substitutions are either neutral or deleterious ( $\omega$ can assume two values, either 0 or 1 ), and iii) a selection model that includes a third category of advantageous substitutions ( $\omega$ can assume three values, 0,1 , or a value estimated from the data). Tests of positive diversifying selection were constructed by comparing twice the log likelihood difference between two models with a $\chi^{2}$ distribution. Each model was run using a neighbor-joining phylogeny as well as two heuristic ML trees calculated in PAUP 4.0 (D. L. Swofford, Sunderland, MA, U.S.A.). Since the results were very similar among the three trees, only those for the tree with the best goodness-of-fit are shown.

\section{Codon usage bias.}

To estimate the extent of codon bias in NIP1, measures of codon usage, such as the codon bias index (Morton 1993), $\mathrm{G}+\mathrm{C}$ content at second and third positions as well as overall, and the effective number of codons (Wright 1990) were estimated in DnaSP.

\section{Variation in NIP1.}

Amino acid sequences of the mature NIP1 were deduced from the DNA sequences, and NIP1 types were numbered. The distribution of these NIP1 types was examined across the populations studied, grouped into five geographical regions, and gene diversity (Nei 1973) was calculated for each region. To test for significant statistical differences in gene diversity among regions, bootstrap analyses were performed with the Resampling Stats software package (version 5.02; Resampling Stats, Inc., Arlington, VA, U.S.A.) to calculate standard deviations. For each bootstrap replication, a random sample of 24 isolates (the sample size of the smallest region, California) was taken from each region, and gene diversity was calculated. This was repeated 10,000 times, and the mean gene diversity and its standard deviation were calculated for each region and compared among each other with $t$-tests applying a Bonferonni correction.

\section{Pathogenicity tests.}

Isolates. The pathogenicity of 35 isolates representing 11 NIP1 types and of four isolates lacking NIP1 was tested on two isogenic pairs of barley cultivars, Atlas CIho 4117 and Atlas 46 CIho 7323 and Ingrid and Turk NIL (supplied by A. Bjørnstad, Agricultural University of Norway, As, Norway). Whenever possible, three isolates were chosen to represent each NIP1 type (Tables 4 and 6). NIP1 type 18 was represented by only one isolate, which could not be recovered from silica gel storage. NIP1 type 14 was represented by a single isolate that was not present in our isolate collection and could not be tested. NIP1 types 8 and 10 were also represented by only one isolate each, and therefore pathogenicity tests for these isolates were repeated twice. Due to limited greenhouse space and resources, the experiment was split into four trials. Each trial always included a negative control (inoculation with water) and positive controls. Four isolates, UK7, AU1, AU2, and AU3, were used as positive controls. Isolates UK7 and AU1 (both AvrRrsl) are virulent on rrs 1 cultivars only (Rohe et al. 1995). They showed the same reaction in the first trial, and therefore, only UK7 was used as a positive control in the following trials. Isolates AU2 and AU3 (both avrRrsl) are virulent on both $r r s l$ and $R r s l$ cultivars (Rohe et al. 1995). Isolate AU3 was used only in the first trial, since it sporulated only weakly later on. The tested isolates were taken from silica gel storage and plated on Difco lima bean agar (Becton, Dickinson and Co., Sparks, MD, U.S.A.) plates amended with kanamycin (50 mg/liter). One colony was transferred to a fresh lima bean agar plate. About two weeks later, 2 $\mathrm{ml}$ of sterile water was added to the plate, and spores were scraped off with a microscope slide. A total of $100 \mu$ l of the spore solution was transferred to a NUNC cryovial filled with sterile silica gel for storage. The rest of the spore suspension was used to inoculate three lima bean agar plates. Two weeks later, water was added to these plates, and spores were again scraped away with a microscope slide. The spore suspension was filtered through two layers of cheesecloth and was centrifuged for $2 \mathrm{~min}$ at $3,000 \times \mathrm{g}$. The pellet was resuspended in fresh water and was centrifuged a second time. Spore concentration was measured with a Thoma cell hematocytometer and was adjusted to $10^{6}$ spores per milliliter.

Inoculations. One-liter pots were filled with Rasenerde Top Dressing (sand, compost, perlite, white peat, mineral fertilizer; Ricoter AG, Aarberg, Switzerland) and were planted with five seeds of the same cultivar. For each isolate, three pots were planted with each cultivar. The plants were grown in the greenhouse with a 14 -h day at $17^{\circ} \mathrm{C}$ and a 10 -h night at $15^{\circ} \mathrm{C}$. Humidity was set at $60 \%$. Inoculations were conducted when the second leaves of the plants were fully developed. A few drops of Tween 20 were added to $60 \mathrm{ml}$ of spore suspension, and this mixture was sprayed onto six pots of five plants each placed on the rotating table of a compressed air inoculation machine. For $48 \mathrm{~h}$ after inoculation, 100\% humidity was ensured by covering the plants with plastic tents, with a humidifier connected to each tent. Two weeks after inoculation, disease symptoms were assessed on the second leaf using a 0 to 5 scale (Reitan et al. 2002). Disease scores below 2 were classified as resistant reactions, between 2 and 3 as moderately resistant, between 3 and 4 as moderately susceptible, and above 4 as susceptible.

\section{Field experiment.}

In 2003, a field experiment was conducted in California at two locations, Davis and Chico. At each location, one plot was planted with the barley cultivar Atlas and another plot with the cultivar Atlas 46. Normally, isolations of $R$. secalis are made from diseased green leaves. However, an unusually dry year resulted in the plants drying out sooner than expected. As a result, diseased leaves were collected at the end of the growing season. $R$. secalis did not sporulate satisfactorily on this very dry material, and therefore, a PCR-based method was used to detect $R$. secalis. DNA extraction was performed directly from leaf material from a total of 176 leaf pieces, with DNeasy plant mini kit (Qiagen, Venlo, The Netherlands). When possible, leaf pieces with recognizable and distinct scald lesions were selected. Multiplex PCR of the mating type idiomorphs (Linde et al. 2003) was used to detect the presence of $R$. secalis DNA. Then, PCR of the NIPl gene with Kilby and 
Robinson's primers (2001) was conducted, to detect the presence of this gene. To confirm the absence of NIPl in the samples for which no amplicon was detected, a second PCR was conducted with a lower annealing temperature (50 instead of $63^{\circ} \mathrm{C}$ ), and a third PCR was conducted with primers NIP1_21F and NIP1_1558R (Table 7). All PCR reactions included positive (DNA from known isolates) and negative (water and barley DNA) controls.

\section{ACKNOWLEDGMENTS}

We would like to thank K. Meles for collecting infected leaves in Jordan, S. Salamati for collecting infected leaves in Sweden, and J. Speakman for providing isolates from France, Germany, and Great Britain. A. Bjørnstad provided Ingrid and Turk NIL barleys. We also acknowledge C. Zollinger for excellent technical assistance. We are grateful to M. Zala for invaluable help with technical problems and S. Banke for help with sequencing. P. Zaffarano provided Southern blots of the Swiss and Ethiopian populations. This work was supported by the Swiss National Science Foundation (grant 31-56874.99)

\section{LITERATURE CITED}

Bergelson, J., Kreitman, M., Stahl, E. A., and Tian, D. 2001. Evolutionary dynamics of plant $R$-genes. Science 292:2281-2285.

Bishop, J. G., Dean, A. M., and Mitchell-Olds, T. 2000. Rapid evolution in plant chitinases: Molecular targets of selection in plant-pathogen coevolution. Proc. Natl. Acad. Sci. U.S.A. 97:5322-5327.

Bjørnstad, Å., Demissie, A., Kilian, A., and Kleinhofs, A. 1997. The distinctness and diversity of Ethiopian barleys. Theor. Appl. Genet. 94:514-521.

Bjørnstad, Å., Patil, V., Tekauz, A., Marøy, A. G., Skinnes, H., Jensen, A., Magnus, H., and MacKey, J. 2002. Resistance to scald (Rhynchosporium secalis) in barley (Hordeum vulgare) studied by near-isogenic lines: I. Markers and differential isolates. Phytopathology 92:710-720.

Brown, A. H. D., Feldman, M. W., and Nevo, E. 1980. Multilocus structure of natural populations of Hordeum spontaneum. Genetics 96:523-536.

Dyck, P. L., and Schaller, C. W. 1961. Inheritance of resistance in barley to several physiologic races of the scald fungus. Can. J. Genet. Cytol. 3:153-164.

Fiegen, M., and Knogge, W. 2002. Amino acid alterations in isoforms of the effector protein NIP1 from Rhynchosporium secalis have similar effects on its avirulence- and virulence-associated activities on barley. Physiol. Mol. Plant Pathol. 61:299-302.

Flor, H. H. 1955. Host-parasite interaction in flax rust-Its genetics and other implications. Phytopathology 45:680-685.

Ford, M. J. 2002. Applications of selective neutrality tests to molecular ecology. Mol. Ecol. 11:1245-1262.

Fu, Y.-X., and Li, W.-H. 1993. Statistical tests of neutrality of mutations. Genetics 133:693-709.

Goodwin, S. B., Allard, R. W., and Webster, R. K. 1990. A nomenclature for Rhynchosporium secalis pathotypes. Phytopathology 80:1330-1336.

Goodwin, S. B., Maroof, M. A. S., Allard, R. W., and Webster, R. K. 1993. Isozyme variation within and among populations of Rhynchosporium secalis in Europe, Australia, and the United States. Mycol. Res. 97:49-58.

Habgood, R. M., and Hayes, J. D. 1971. The inheritance of resistance to Rhynchosporium secalis in barley. Heredity 27:25-37.

Hahn, M., Jüngling, S., and Knogge, W. 1993. Cultivar-specific elicitation of barley defense reactions by the phytotoxic peptide NIP1 from Rhynchosporium secalis. Mol. Plant-Microbe Interact. 6:745-754.

Houston, B. R., and Ashworth, L. J. 1957. Newly determined races of the barley scald fungus in California. Phytopathology 47:525.

Hughes, A. L., and Nei, M. 1988. Pattern of nucleotide substitution at major histocompatibility complex class I loci reveals overdominant selection. Nature 335:167-170.

Johnson, M., Penner, G. A., and Knogge, W. 1996. Necrosis inducing peptide 1 involvement in a gene-for-gene relationship with $R h 3$ of barley cultivar Atlas 46. Pages 726-728 in: 5th International Oat Conference and 7th International Barley Genetics Symposium, University of Saskatchewan, Saskatoon, Canada.

Joosten, M. H. A. J., Vogelsang, R., Cozijnsen, T. J., Verberne, M. C., and De Wit, P. J. G. M. 1997. The biotrophic fungus Cladosporium fulvum circumvents $C f$-4-mediated resistance by producing unstable AVR4 elicitors. Plant Cell 9:367-379.

Jukes, T. H., and Cantor, C. R. 1969. Evolution of protein molecules. Pages 21-132 in: Mammalian Protein Metabolism. H. N. Munro, ed. Academic Press, New York.
Kang, S., Lebrun, M. H., Farrall, L., and Valent, B. 2001. Gain of virulence caused by insertion of a Pot 3 transposon in a Magnaporthe grisea avirulence gene. Mol. Plant-Microbe Interact. 14:671-674.

Kilby, N. J., and Robinson, J. 2001. Pathotypes and NIP1 gene sequences of Finnish Rhynchosporium secalis isolates from barley, couch grass and rye. Euphytica 120:265-272.

Kimura, M. 1983. The Neutral Theory of Molecular Evolution. Cambridge University Press, New York.

Knogge, W., Fiegen, M., Gierlich, A., Kruse, D., Li, V., Liedgens, H. van't Slot, A., Steiner, S., and Vöcking, R. 1999. Host-pathogen recognition in the barley-Rhynchosporium pathosystem. Pages 199-205 in: Septoria on Cereals: A Study of Pathosystems. J. A. Lucas, P. Bowyer, and H. M. Anderson, eds. CABI Publishing, Wallingford, U.K.

Kumar, S., Tamura, K., Jakobsen, I. B., and Nei, M. 2001. MEGA2: Molecular evolutionary genetics analysis software. Bioinformatics 17:1444-1445.

Lehnackers, H., and Knogge, W. 1990. Cytological studies on the infection of barley cultivars with known resistance genotypes by Rhynchosporium secalis. Can. J. Bot. 68:1953-1961.

Linde, C. C., Zala, M., Ceccarelli, S., and McDonald, B. A. 2003. Further evidence for sexual reproduction in Rhynchosporium secalis based on distribution and frequency of mating-type alleles. Fung. Genet. Biol. 40:115-125.

Luderer, R., Takken, F. L. W., de Wit, P. J. G. M., and Joosten, M. H. A. J. 2002. Cladosporium fulvum overcomes $C f$-2-mediated resistance by producing truncated AVR2 elicitor proteins. Mol. Microbiol. 45:875884.

MacIntyre, R. J. 1985. Molecular Evolutionary Genetics. Plenum Press, New York.

McDonald, B. A., McDermott, J. M., Allard, R. W., and Webster, R. K. 1989. Coevolution of host and pathogen populations in the Hordeum vulgare-Rhynchosporium secalis pathosystem. Proc. Natl. Acad. Sci. U.S.A. 86:3924-3927.

McDonald, B. A., Zhan, J., and Burdon, J. J. 1999. Genetic structure of Rhynchosporium secalis in Australia. Phytopathology 89:639-645.

Morton, B. R. 1993. Chloroplast DNA codon use: Evidence for selection at the $p s b$ A locus based on tRNA availability. J. Mol. Evol. 37:273-280.

Nei, M. 1973. Analysis of gene diversity in subdivided populations. Proc. Natl. Acad. Sci. U.S.A. 70:3321-3323.

Nei, M., and Gojobori, T. 1986. Simple methods for estimating the numbers of synonymous and nonsynonymous substitutions. Mol. Biol. Evol. 3:418-426.

Reitan, L., Grønnerød, S., Ristad, T. P., Salamati, S., Skinner, H., Waugh, R., and Bjørnstad, A. 2002. Characterization of resistance genes against scald (Rhynchosporium secalis (Oudem.) J.J. Davis) in barley (Hordeum vulgare L.) lines from central Norway, by means of genetic markers and pathotype tests. Euphytica 123:31-39.

Rohe, M., Gierlich, A., Hermann, H., Hahn, M., Schmidt, B., Rosahl, S., and Knogge, W. 1995. The race-specific elicitor, NIP1, from the barley pathogen, Rhynchosporium secalis, determines avirulence on host plants of the Rrs 1 resistance genotype. EMBO (Eur. Mol. Biol. Organ.) J. 14:4168-4177.

Rozas, J., and Rozas, R. 1999. DnaSp version 3: An integrated program for molecular population genetics and molecular evolution analysis Bioinformatics 15:174-175.

Salamati, S., Zhan, J., Burdon, J. J., and McDonald, B. A. 2000. The genetic structure of field populations of Rhynchosporium secalis from three continents suggests moderate gene flow and regular recombination. Phytopathology 902:901-908.

Shaner, G., Stromberg, E. L., Lacy, G. H., Barker, K. R., and Pirone, T. P. 1992. Nomenclature and concepts of pathogenicity and virulence. Annu. Rev. Phytopathol. 30:47-66.

Shipton, W. A., Boyd, W. J. R., and Ali, S. M. 1974. Scald of barley. Rev. Plant Pathol. 53:839-861.

Søgaard, B., and von Wettstein-Knowles, P. 1987. Barley: Genes and chromosomes. Carlsberg Res. Commun. 52:123-196.

Stahl, E. A., and Bishop, J. G. 2000. Plant-pathogen arms races at the molecular level. Curr. Opin. Plant Biol. 3:299-304.

Stotz, H. U., Bishop, J. G., Bergmann, C. W., Koch, M., Albersheim, P., Darvill, A. G., and Labavitch, J. M. 2000. Identification of target amino acids that affect interactions of fungal polygalacturonases and their plant inhibitors. Physiol. Mol. Plant Pathol. 56:117-130.

Tajima, F. 1989. Statistical method for testing the neutral mutation hypothesis by DNA polymorphism. Genetics 123:585-595.

Van der Biezen, E. A., and Jones, J. D. G. 1998. Plant disease-resistance proteins and the gene-for-gene concept. Trends Biochem. Sci. 23:454 456.

van Kan, J. A. L., van den Ackerveken, G. F. J. M., and de Wit, P. J. G. M. 1991. Cloning and characterization of cDNA of avirulence gene $a v r 9$ of the fungal pathogen Cladosporium fulvum, causal agent of tomato leaf 
mold. Mol. Plant-Microbe Interact. 4:52-59.

van't Slot, K. A. E. 2002. Structure and function of the (a)virulence protein NIP1 of Rhynchosporium secalis. Ph.D. dissertation, Wageningen University, The Netherlands.

van't Slot, K. A. E., van den Burg, H. A., Kloks, C. P. A. M., Hilbers, C. W., Knogge, W., and Papavoine, C. H. M. 2003. Solution structure of the plant disease resistance-triggering protein NIP1 from the fungus Rhynchosporium secalis shows a novel $\beta$-sheet fold. J. Biol. Chem. 278:45730-45736.

Webster, R. K., Jackson, L. F., and Schaller, C. W. 1980. Sources of resistance in barley to Rhynchosporium secalis. Plant Dis. 64:88-90.

Weir, B. S. 1979. Inferences about linkage disequilibrium. Biometrics $35: 235-254$

Wevelsiep, L., Kogel, K.-H., and Knogge, W. 1991. Purification and characterization of peptides from Rhynchosporium secalis inducing necrosis in barley. Physiol. Mol. Plant Pathol. 39:471-482.

Wevelsiep, L., Rüpping, E., and Knogge, W. 1993. Stimulation of barley plasmalemma $\mathrm{H}^{+}$-ATPase by phytotoxic peptides from the fungal pathogen Rhynchosporium secalis. Plant Physiol. 101:297-301.

Wolfe, K. H., and Li, W.-H. 2003. Molecular evolution meets the genom- ics revolution. Nature Genet. 33:255-265.

Wright, F. 1990. The "effective number of codons" used in a gene. Gene 87:23-29.

Yang, Z. 1997. PAML: A program package for phylogenetic analysis by maximum likelihood. Comp. Appl. Biosci. 13:555-556.

Yeh, F. C., Yang, R.-C., Boyle, T. B. J., Ye, Z.-H., and Mao, J. X. 1999. POPGENE, the user-friendly shareware for population genetic analysis, Molecular Biology and Biotechnology Centre, University of Alberta, Edmonton, Canada.

Yitbarek, s., Berhanie, L., Jikadu, A., van Leur, J. A. G., Grando, S., and Ceccarelli, S. 1998. Variation in Ethiopian barley landrace populations for resistance to barley leaf scald and net blotch. Plant Breeding 117:419-423.

Zareie, R., Melanson, D. L., and Murphy, P. J. 2002. Isolation of fungal cell wall degrading proteins from Barley (Hordeum vulgare L.) leaves infected with Rhynchosporium secalis. Mol. Plant-Microbe Interact. 15:1031-1039.

Zhang, J., Kumar, S., and Nei, M. 1997. Small-sample tests of episodic adaptive evolution: A case study of primate lysozymes. Mol. Biol. Evol. $14: 1335-1338$ 